Journal of Research in Technical Careers

December 2020, Vol. 4, No. 2

(C) Author(s)

\title{
Entry-Level Workplace Competencies Needed by Graduates of a Community College Agriculture Program: A Midwest Case Study Using the Delphi Technique
}

\author{
Blake C. Colclasure \\ Doane University
}

\begin{abstract}
Community colleges have a strong history of providing vocational education and occupational training to meet changing workforce demands of local industries. In the Midwest, agricultural industries have expressed an expanding need for middle-skilled workers with postsecondary, prebaccalaureate credentials. The 21 st century agricultural landscape has changed as a result of the need for efficiency and sustainability, and resulting emergent agricultural technologies. Community colleges will be integral to establishing a qualified agriculture workforce for entry-level, middle-skilled positions. This study utilized a modified Delphi approach to identify entry-level workplace competencies needed by graduates of a community college agriculture program. Delphi panel experts represented leaders from the agronomy-based agriculture industry within the college's district, and initially identified 87 desired workforce competencies. Fifty-eight competencies achieved consensus from the Delphi panel and were categorized by themes: soft skills (26), agronomy-based technical skills (12), technology-based technical skills (9), agriculture mechanic/operatorbased technical skills (3), general technical skills (4), and agribusiness-based technical skills (4). Results of this study can be used to inform community college agriculture program development and can be used as a case study for assessing workforce needs of local agricultural industries.
\end{abstract}

Keywords: agriculture, community college, Delphi, industry needs assessment, skills

\section{Introduction}

The rise of the two-year or junior college in the early 20th century changed the landscape of higher education in the United States. Junior colleges, or later named community colleges, have become symbols for affordable, local, and open access to higher education. The two-year institution has had multiple missions and has undergone periods of conflicting change since their establishment (Beach, 2010; Jacobs \& Worth, 2019). Ironically, junior colleges first served as gatekeepers to the four-year institution. Educational reformers believed that junior colleges could efficiently cover general

(i) $\odot$ Creative Commons CC-BY-NC-ND: This article is distributed under the terms of the Creative Commons Attribution 4.0 License (http://creativecommons.org/licenses/by/4.0/) which allows others to download your works and share them with others as long as they credit you, but they can't change them in any way or use them commercially. 
coursework for freshman and sophomore students, thereby limiting only successful students to transfer to a program for specialized professional study and disciplinary research (Beach, 2010). However, as the number of two-year institutions expanded in the 1930s, so did their missions. Community leaders recognized the value of a local college as a tool for social mobility, community organization, and regional economic development (Beach, 2010; Dougherty, 1994). As a result, vocational education and occupational training became woven into the identity of the community college. Today, community colleges play an integral role in training the 21 st century workforce (Jacobs \& Worth, 2019; Soliz, 2016).

\section{Vocational Education and the Community College}

Throughout the last century, the emphasis on occupational or vocational education in community colleges grew to meet the changing economic and educational needs of the country. In 1939, the American Association of Junior Colleges established a Commission on Junior College Terminal Occupations to promote workforce education and terminal degrees at a national level (Cohen \& Brawer, 1996). Following World War II, the Truman Commission garnered support for the creation of more community colleges and identified postsecondary training needs for "semiprofessional" occupations (Grubb \& Lazerson, 2004; Jacobs \& Worth, 2019). The most rapid growth of community colleges occurred during the 1960s and 1970s (Beach, 2010), and by 1975 there were over 1,000 community colleges with more than five million students (Cohen, 1998).

The close relationship between community colleges and their local communities fostered innovative partnerships between two-year institutions and employers of the regional workforce. In the 1980s, many community colleges established new centers for technical training and contract training programs (Levin et al., 2006). The emergence of contract training programs allowed community colleges to provide customized training designed for the specific needs of local employers (Leigh, 2005) while also capturing additional revenue streams for the college. Many employers found these programs extremely beneficial, filling training needs required for future or incumbent workers (Spaulding \& Martin-Caughey, 2015), and paid for tuition and fees associated with trainings (Leigh, 2005). Lastly, the new partnerships revitalized vocational education by aligning the skills needed in current labor markets to educational programs (Dougherty \& Bakia, 2000).

In the beginning of the 21 st century, the number of short, vocational credentials continued to grow and, in fact, more than doubled between 2000 and 2012 (Soliz, 2016). Community college enrollment as a whole also remained strong, and in 2013 boasted enrollment of more than seven million students, approximately 40 percent of all postsecondary students (Kena et al., 2015). The growth in workforce development programs was catalyzed by the economic recession of 2008-2010. In 2009, under the Obama administration, two billion dollars was awarded to the U.S. Department of Labor for the establishment of the Trade Adjustment Assistance Community College and Career Training Program (Jacobs \& Worth, 2019). The program, which ran through 2018, was "a major investment to increase the ability of community colleges to address the 
challenges of today's workforce" (U.S. Department of Labor, para 1., n.d.). In total, nearly 2,700 programs of study were developed or redesigned to align curriculum with industry, accelerate learning strategies, and provide hands-on experience to help adults learn skills that lead to family-supporting jobs (U.S. Department of Labor, 2018). In 2019 , there were 1,051 community colleges serving approximately seven million forcredit students and five million non-credit students (American Association of Community Colleges, 2019).

Today's community colleges continue to play a central role in higher education, offering a growing variety of students access to affordable education. Jacobs and Dougherty (2006) acknowledged that community colleges, compared to other institutions of higher education, have unique characteristics, such as close proximity to local businesses, low cost, technical expertise, experience in teaching adult learners, and organizational flexibility. These characteristics have positioned community colleges to be leaders in local workforce development and can provide efficient and flexible education responsive to market demands (Levin et al., 2006). Community college administrators and government officials have also acknowledged community colleges as drivers of local workforce and economic development, serving a unique educational niche (Dougherty \& Bakia, 2000). Jacobs and Worth (2019) reported that community colleges are the best suited institutions of higher education to address the national workforce system in the United States. However, today's changing demands from the community, unstable government funding, and a changing job market are putting unique pressure on the sustainability of community colleges (Fletcher, 2017). In an era of yet more change and pressure in higher education (Lukens, 2019), it is imperative that community colleges seek to establish new and innovative work ready programs aligned to an advancing economy and meeting student, community, industry, and institutional needs.

\section{The Agricultural Skills Gap}

The agricultural industry of the 21 st century has become more complex and globalized. The needs of a population that is expected to reach nine billion by the year 2050 will set unprecedented demands on global agriculture production (National Research Council, 2009). Additionally, social, political, and environmental issues will challenge the ability of the agricultural industry to meet these demands (National Research Council, 2009). Twenty-first century technological advancements in agriculture have become essential to provide a more efficient, affordable, and environmentally sustainable food supply in the face of a changing climate (Little, 2019). The rapid pace of technological change has redefined the skillset needed by the agricultural workforce. The agricultural workforce of the 21 st century must not only be critical thinkers and collaborative problems solvers (National Research Council, 2009), but must be skilled in emerging agricultural technologies (Parker et al., 2009).

Carnevale et al. (2013) analyzed job growth after the 2008 economic recession and found that jobs created post-recession differed in composition compared to the jobs lost during the recession. The emerging jobs in agriculture require workers with a new skillset, which has led to a shortage of qualified workers (Whittaker \& Williams, 2016). 
The aging demographic of the agricultural worker is compounding this shortage (Carlisle et al., 2019). The number of vacant job openings and the limited pipeline of individuals capable of filling these positions has led to an agricultural skills and employment gap.

According to the National Skills Coalition (2017), "middle-skilled jobs, which require education beyond high school but not a four-year degree, make up the largest part of America's and [the Midwest's] labor market" (para. 1). This report indicated that key industries in midwestern states, such as Illinois, are "unable to find enough sufficiently trained workers to fill these jobs" (National Skills Coalition, 2017, para. 1). The report concluded that over half of all jobs in 2015 were middle-skill, and between 2014 and 2024, half of all new job openings will be middle-skill.

The Kansas Department of Agriculture (2016) sought to better understand the workforce needs of agriculture employers in Kansas. Researchers distributed an agricultural workforce needs assessment survey to agricultural employers across Kansas. A total of 250 responses from industry were received and confirmed the agriculture skills and employment gap. Thirty-six of respondents reported vacancies, and among those vacancies $36 \%$ were considered entry-level positions. Furthermore, nearly $44 \%$ of respondents indicated that they planned to expand business operations in the next three years, and approximately a quarter of that expansion would be entry-level positions. Although over $80 \%$ of respondents indicated that they provide their own training opportunities to employees, over $66 \%$ of respondents desired to work with local education providers to establish training programs. The report proclaimed that "a lack of a skilled agricultural workforce is a top inhibitor of growth and expansion for many Kansas agriculture entities" (Kansas Department of Agriculture, 2016, para. 1).

\section{Closing the Agriculture Skills Gap: Community College Agricultural Education}

Erickson et al. (2018) conducted a large industry survey of agricultural retailers. The researchers questioned respondents on the difficulty of locating qualified applicants for precision agricultural positions and examined perceived minimum educational requirements for those positions. Respondents indicated that there was difficulty in filling these positions. In fact, at least one-third of respondents indicated that it took more than 90 days to fill the roles of agronomist, precision equipment technician, technical support, and precision sales specialist. Perceived minimum educational requirements varied by position, but most notably, $18 \%$ of respondents indicated that a two-year community college degree is needed to be an equipment technician, and $46 \%$ of respondents indicated that a two-year community college degree will be needed five years into the future. Only $7 \%$ of respondents indicated that a two-year community college degree is needed to be a precision sales specialist, but that number climbed to $27 \%$ for future projections. In fact, future projections showed that community college degrees will be in more demand for all positions, while the need to have a bachelor's degree decreased for all positions except just one, agronomist. According to Torpey (2018), employment for all occupations requiring an associate's degree or postsecondary certificate is expected to grow $11 \%$ from 2016 to 2026. 
Community colleges will be vital in providing a pipeline of qualified workers for entry-level, middle-skill jobs within the United States agricultural industry. True to the mission of the community college, workforce programs should be aligned to the needs of industry within the community college district (Holzer, 2015) while also designed to promote students' long-term success (Soliz, 2016). The current study focused on an emerging community college agriculture program in the Midwest and identified the entry-level workplace skills and competencies sought by agricultural employers within the college's district.

\section{Conceptual Framework}

Scheer et al. (2011) summarized that "a competency approach to human resource management and academic curriculum development can be a useful framework for building organizational capacity and ensuring academic program relevancy" (p. 65). McClelland (1973) described competencies as characteristics that underlie human performance. Athey and Orth (1999) further define competencies as the necessary skills, knowledge, attitudes, and behavior required for individual, organizational, and program success. Identifying employee competencies that characterize desired worker performance can positively impact organizational outcomes (McClelland, 1973), especially when used to recruit employees (Peregrin, 2014).

The Human Capital Theory (Becker, 1993) explores how human competencies increase the value of an organization, and is described by Langelett (2002) as the "knowhow of the work force that increases the productivity of each worker" (p. 1). Organizations that employ and continuously invest in a highly competent workforce expand the human capital of their organization. McCracken et al. (2017) explained, "there is a growing consensus in both academia and industry that human capital has a key role to play in [an organization's] strategic outcomes" (p. 6). Additionally, an organization's ability to adapt and innovate in a technologically advanced society may be contingent upon the organization's human capital (Hampf et al., 2017). Investment in human capital extends beyond improving organizational success and has tremendous benefit to the individual, including playing an important role in the determination of wages (Arteaga, 2018), and career satisfaction and success (Guo et al., 2012).

Educational programs that are aligned to industry needs and desired workforce competencies can produce a qualified workforce that increases an organization's human capital. Therefore, work-ready educational programs should consistently evaluate industry needs in order to align program learning objectives and to identify and close existing employee skills gaps (Easterly et al., 2017). In the Understanding by Design (Wiggins \& McTighe, 2005) approach to curriculum development, curriculum developers first identify what students should be able to know and do after they are exposed to an educational program. After these big ideas and skills are identified, curriculum developers then determine how to assess student performance and design appropriate instructional techniques. Using the Understanding by Design framework to develop workforce education that is well aligned with industry needs first requires a needs 
assessment of local industry. The Delphi research approach is one tool among many to collect data that can inform the first steps of program development.

Delphi studies can be used to develop a consensus from a group of subject matter experts through multiple rounds of anonymous feedback (Warner, 2014). Previous research using the Delphi technique has collected expert opinions on desired skills and competencies needed in the agricultural industry and has informed curriculum development. In an analysis of School-based Agricultural Education programs and Supervised Agricultural Experiences, Ramsey and Edwards (2011) conducted a modified Delphi to identify agricultural industry experts' beliefs on the technical skills needed for entry-level employment. Sixty entry-level technical skills were identified. Thirteen communication skills, such as dependability, reliability, and oral communication, garnered consensus, as well as 31 skills related to the animal sciences, six skills related to plant and soil science, and three skills related to agribusiness management.

Conner et al. (2013) conducted a modified Delphi to determine the competencies and experiences needed by entry level agricultural development practitioners. The panelists identified and met consensus on 26 competencies. Identified competencies ranged from demonstrating good communication skills to exhibiting critical thinking skills. The researchers suggested that the identified competencies be used to inform the preparation of college students for careers in international agricultural development.

Sapp et al. (2019) formed a panel of south Florida agricultural industry members and educators, and utilized the Delphi technique to determine a consensus of competencies needed by high school graduates for entry-level employment in agricultural and environmental practices in Hardy County, Florida. The panel achieved consensus on 83 competencies. Twenty life/leadership skills were identified and included characteristics such as work ethic, responsibility, and teamwork. Forty-four agricultural knowledge/skills were identified, including items such as ability to read pesticide labels, ability to understand material safety data sheets, and understanding plant nutrition and soil conservation. Lastly, the ability to perform 18 basic agriculture tasks were emphasized, including tasks such as ability to measure accurately and converting fractions to decimals. The researchers recommended that findings be used to develop courses, course outlines, and curriculum for agricultural education programs in south Florida. The researchers encouraged similar research in other geographical areas to identify the knowledge, skills, and competencies desired of regional agriculture industry.

\section{Purpose and Objective}

This research explored the perceptions of agriculture employers within a community college district that was uniquely positioned in the epicenter of Midwest grain production. At the time of the study, the college's district stretched across portions of three counties and included over a dozen School-based Agricultural Education programs. A growing number of agriculture-based companies mainly focusing on some aspect of agronomic crop production were located in the college's district. The purpose of this study was to establish working relationships between the college and agriculture industry 
located within the college's district. This study sought to develop a list of desired competencies needed by graduates of a two-year agriculture program for entry-level positions within local agribusinesses. The list of competencies would be used as one data set among many to inform the development of work-ready, agricultural education programs. Furthermore, it was anticipated that this research would serve as a model for community college agriculture program development based upon stakeholder needs.

The research objective used to guide this study was to identify competencies needed by graduates of a community college work-ready, agriculture program for entrylevel employment in local agricultural industries.

\section{Methods}

This research was approved through the college's Human Subjects Research Review Board (HSRRB). A modified Delphi technique was selected as the best research method to address the objective of this study. Delphi approaches have been used previously to establish programmatic objectives (Diaz et al., 2018; Long \& Morgan, 2010), to revise educational curriculum (Lundy et al., 2017), and to identify essential professional competencies needed in agricultural settings (Edgar et al., 2012; Conner et al., 2013; Ramsey \& Edwards, 2011; Sapp et al., 2019). Stewart (2001) suggested that a modified Delphi can be used to gather a consensus of knowledge from experts when distant communication is convenient over traditional face-to-face settings. The steps used to conduct the Delphi in this study followed recommendations by Geist (2010): (1) form a panel of topic experts who are willing to participate; (2) deliver Round 1 of the Delphi that requests that participants answer an initial question; (3) review responses and develop a succeeding questionnaire; (4) deliver Round 2 of the Delphi by requesting that participants complete the succeeding questionnaire; and (5) repeat steps three and four until a consensus is identified by criteria established a priori.

\section{Identification of Panel Respondents}

Agricultural industry representatives within the college's district were sought to participate in the Delphi panel. The criteria to identify panel members included: (a) the panel member must have an appropriate industry position that represents the professional knowledge required of this study (business owner, manager/supervisor, human resources personnel/recruiter, subject matter expert, etc.); and (b) the panel member must represent the agriculture industry within the college's district. It was also determined that panel members must represent the breadth of agronomy-related industry within the district and should include members representing enterprises of various sizes (micro enterprises, small enterprises, medium-sized enterprises, and large enterprises) (Organisation for Economic Cooperation and Development, 2015). Lastly, it was determined that no more than two individuals from the same enterprise could serve on the panel. A list of 33 potential panel members was identified from an exhaustive search of agronomy-related agriculture industries within the college's district. The list served as a purposive sampling frame for the study. The sampling frame was agreed upon by a three-person panel of 
regional agricultural leaders to represent the breadth of agricultural enterprises in the college's district.

\section{Instrumentation}

The instrument used to complete all three rounds of the study was an online questionnaire developed and delivered through Qualtrics. Invitations to complete each round of the study followed the Tailored Design Method (Dillman et al., 2014). A customized email was delivered to each panel member with a link to participate. When participant responses dropped considerably, a reminder email was sent to all nonrespondents. A second follow-up email was sent via the same method.

In the first round of the study, each participant received a link to answer the openended question "please list the skills and competencies that you believe graduates of a two-year (non-transfer) community college agriculture program should have in order to be prepared to enter the local agriculture workforce." The definition and emphasis of the terms "non-transfer" and "local" agriculture industry were added for clarity. Non-transfer was defined by a certificate, degree, or other educational programming at the community college level not intended for the transfer of credits to a four-year institution. Local was defined as within the college's district.

All open-ended responses received from Round 1 were analyzed and likestatements were combined. The statements were then categorized into emergent topics (e.g. soft skills, agronomy-based technical skills, etc.). A four-person panel of experts reviewed the statements, combining of statements, and categorization of statements into identified topics. The panel of experts consisted of a community college agriculture faculty member and agriculture program leader, an associate dean of science, a dean of STEM and business, and an assistant professor of agricultural communications at a state land-grant institution. All members of the panel of experts had advanced education in curriculum design and workforce development, and two of the panel of experts held doctoral degrees specific to agricultural education and communication.

In Round 2 of the Delphi, participants were sent the list of competencies collected and categorized in Round 1. Each participant identified their extent of agreement on whether each competency is needed by community college agriculture graduates who enter the local agricultural workforce. A six-point, Likert scale was used to assess agreement for each statement $(1=$ strongly disagree, $2=$ disagree, $3=$ slightly disagree, $4=$ slightly agree, $5=$ agree, $6=$ strongly agree). Statements that received an agree or strongly agree by at least $65 \%$ of the panel were established a priori to advance to the third round of the Delphi. Statements that did not meet this criteria were removed.

In the third round, participants were sent the list of skills and competencies that met the criteria to advance. The order of categories and statements was randomly rearranged in the third round of the Delphi. Once again, each participant was asked to identify their extent of agreement for whether each competency is needed by community college agriculture graduates who enter the local agricultural workforce. The same sixpoint, Likert scale used in Round 2 was used in the third round. Statements that received an agree or strongly agree by at least $65 \%$ of panel respondents were deemed to have 
reached consensus. Descriptive data were analyzed using Statistical Package for the Social Sciences (SPSS) version 25.

\section{Results}

Nineteen of the 33 members in the sampling frame responded and agreed to participate in the research study, indicating a 57.6\% response rate. The 19 -member panel of agricultural industry representatives was determined to be an ideal panel size, as previous research recommended to have at least 13 expert panelists to achieve a reliability of 0.9 (Dalkey, 2002). Thirteen panel members were male and six were female. Employment positions of panel members were business/farm owner $(n=7)$, manager or supervisor $(n=7)$, human resources personal/recruiter $(n=3)$, and subject matter expert $(n=2)$. All but one panel member had six or more years of experience in the industry, and 11 panel members had 16 or more years of industry experience. The size of industries represented ranged from micro enterprises with fewer than 10 employees $(n=7)$ to large enterprises with 250 or more employees $(n=5)$. Table 1 illustrates Delphi panel participant demographics.

\section{Round 1}

Table 1. Participant Demographics of Delphi Panel $(n=19)$

\begin{tabular}{lll}
\hline Panel Member Demographics & $n$ & $\%$ \\
\hline Gender & 13 & \\
Male & 6 & $68.4 \%$ \\
Female & & $31.6 \%$ \\
Employment Position & 7 & $36.8 \%$ \\
$\quad$ Business Owner/Farmer & 7 & $36.8 \%$ \\
Manager/Supervisor & 3 & $15.8 \%$ \\
Human Resources/Recruiter & 2 & $10.6 \%$ \\
Subject Matter Expert & & \\
Years of Agriculture Industry Work Experience & 1 & $5.3 \%$ \\
Less than 6 Years & 7 & $36.8 \%$ \\
6 to 15 Years & 5 & $26.3 \%$ \\
16 to 25 Years & 6 & $31.6 \%$ \\
More than 25 Years & & \\
Size of Enterprise Owned or Employed In & 7 & $36.8 \%$ \\
Micro Enterprise (fewer than 10 employees) & 3 & $15.8 \%$ \\
Small Enterprise (10 to 49 employees) & 4 & $21.1 \%$ \\
Medium-Sized Enterprise (50 to 249 employees) & 5 & $26.3 \%$ \\
Large Enterprise (250 or more employees) &
\end{tabular}


Sixteen of the 19 panel members completed the first round of the study, indicating a $84.2 \%$ response rate. Panel members were requested to provide open responses to the question "please list the skills and competencies that you believe graduates of a two-year (non-transfer) community college agriculture program should have in order to be prepared to enter the local agriculture workforce." A total of 160 statements were received from members of the panel. Responses were coded into topic areas. Six topic areas emerged: soft skills; technology-based technical skills; agronomy-based technical skills, agribusiness technical skills, agriculture mechanic/operator-based technical skills, and general technical skills. Like-statements in each topic area were combined to produce a total of 87 competencies ( 30 soft skills, 19 agronomy-based technical skills, 14 technology-based technical skills, 12 agriculture mechanic/operator-based skills, seven general technical skills, and five agribusiness technical skills). A four-person panel of agriculture faculty members and administrators agreed that the 87 competencies were an accurate summary of the original 160 statements received.

\section{Round 2}

A succeeding questionnaire consisting of the 87 identified competencies, broken down by category, was sent to Delphi panel members in Round 2 of the survey. In this round each panel member rated their extent of agreement on whether each competency was needed by graduates for entry-level employment in local agribusiness. Sixteen of the 19 panel members completed the second round of the survey, indicating a response rate of $84.2 \%$. Twenty-six of 30 soft skills were rated as agree or strongly agree by at least $65 \%$ of panel respondents, and advanced to the third round of the Delphi. Other competencies that advanced included: 12 of 19 agronomy-based technical skills, nine of 14 technology-based technical skills, four of 12 agriculture mechanic/operator-based skills, six of seven general technical skills, and four of five agribusiness technical skills.

\section{Round 3}

A succeeding questionnaire consisting of the 61 competencies advancing to Round 3 were sent to the Delphi panel. The order of categories and competencies within each category was randomly arranged. Again, each panel member rated their extent of agreement to whether each competency was needed by graduates for entry-level employment in local agribusiness. Competencies that received an agree or strongly agree by at least $65 \%$ of respondents in the third round were determined to have reached consensus. Responses to the third round of the Delphi were received from 16 of the 19 panelists, indicating a response rate of $84.2 \%$. A total of 58 skills reached consensus. Results for each round of the study are presented according to the six emergent categories. 
Table 2. Delphi Panel Results for Soft Skills and Competencies

\begin{tabular}{lccc}
\hline \multicolumn{1}{c}{ Round $1(n=16)$} & Round $2(n=16)$ & Round $3(n=16)$ \\
\cline { 1 - 2 } Skill / Competency Identified & Strongly Agree/Agree $\%$ & Strongly Agree/Agree $\%$ \\
\hline Ability to ask important questions & 100 & 100 \\
Common sense & 100 & 100 \\
Honesty & 100 & 100 \\
Verbal communication & 100 & 100 \\
Meeting deadlines & 93.8 & 100 \\
Patience & 93.8 & 100 \\
Problem solving & 93.8 & 100 \\
Self-motivation & 93.8 & 100 \\
Time management & 93.8 & 100 \\
Willingness to learn & 93.8 & 100 \\
Customer service & 87.5 & 100 \\
Listening skills & 100 & 93.8 \\
Following directions & 93.8 & 93.8 \\
Proper phone etiquette & 93.8 & 93.8 \\
Flexibility/adaptability & 87.5 & 93.8 \\
Teamwork & 93.8 & 93.8 \\
Building rapport & 81.3 & 93.8 \\
Friendliness & 81.3 & 93.8 \\
Non-verbal communication & 100 & 87.5 \\
Proper email etiquette & 93.8 & 87.5 \\
Written communication & 93.8 & 87.5 \\
Organization & 87.5 & 87.5 \\
Multitasking & 81.3 & 81.3 \\
Leadership & 75.0 & 81.3 \\
Self-aware of passions & 68.8 & 75.0 \\
Employee management & 68.8 & 68.8 \\
Networking* & $62.5^{*}$ & - \\
Presentation skills & $56.3^{*}$ & - \\
Work/life balance & $56.3^{*}$ & - \\
Planning events & $31.3^{*}$ & - \\
\hline Note. ${ }^{*}$ conssinn & & \\
\hline
\end{tabular}

Note. ${ }^{*}$ consensus not met

\section{Soft Skills}

Twenty-six soft skill competencies achieved consensus at the conclusion of the Delphi. In fact, 11 competencies were rated agree or strongly agree by $100 \%$ of respondents in the third round. The ability to ask important questions, verbal communication, and customer service were some of the competencies achieving highest agreement. Proper etiquette was found to be an essential competency, identified by both phone etiquette and email etiquette. Leadership and employee management also achieved consensus. All soft skill competencies that had advanced to the third round achieved 
Table 3. Delphi Panel Results for Agronomy-based Technical Skills

\begin{tabular}{|c|c|c|}
\hline Round $1(n=16)$ & Round $2(n=16)$ & Round $3(n=16)$ \\
\hline Skill / Competency Identified & rongly Agree/Agree \% & Strongly Agree/Agree \% \\
\hline $\begin{array}{l}\text { Understanding general crop growth and } \\
\text { physiology }\end{array}$ & 87.5 & 87.5 \\
\hline Identifying nutrient deficiencies in crops & 75.0 & 87.5 \\
\hline Maintaining healthy soils & 75.0 & 87.5 \\
\hline Identifying crop diseases & 87.5 & 81.3 \\
\hline Managing insects & 87.5 & 81.3 \\
\hline Identifying weed species & 81.3 & 81.3 \\
\hline Managing weeds & 81.3 & 81.3 \\
\hline $\begin{array}{l}\text { Understanding of tillage/field cultivation } \\
\text { practices }\end{array}$ & 81.3 & 81.3 \\
\hline Identifying insect species & 75.0 & 81.3 \\
\hline Interpreting soil macro and micro nutrients & 68.8 & 75.0 \\
\hline Interpreting soil $\mathrm{pH}$ & 68.8 & 75.0 \\
\hline Sampling soils & 68.8 & 68.8 \\
\hline Extending seasonal operations for farm profit & $62.5^{*}$ & - \\
\hline Handling grain for farm profit ${ }^{*}$ & $62.5^{*}$ & - \\
\hline Managing nutrient availability ${ }^{*}$ & $56.3^{*}$ & - \\
\hline $\begin{array}{l}\text { Creating biodiverse habitats (e.g. beneficial } \\
\text { insect populations, waterways, fence rows) }\end{array}$ & $50.0^{*}$ & - \\
\hline Interpreting soil texture ${ }^{*}$ & $50.0^{*}$ & - \\
\hline Implementing cover crops* & $37.5^{*}$ & - \\
\hline Understanding soil biology and chemistry* & $37.5^{*}$ & - \\
\hline
\end{tabular}

Note. ${ }^{*}$ consensus not met

consensus. Table 2 illustrates the soft skills identified and those reaching consensus in each round of the study.

\section{Agronomy-based Technical Skills}

Twelve agronomy-based technical skills achieved final consensus. The three skills most agreed upon were understanding general crop growth and physiology, identifying nutrient deficiencies in crops, and maintaining healthy soils. Other skills achieving consensus also pertained to soil management, including understanding tillage/field cultivation practices, interpreting soil macro and micro nutrients, interpreting $\mathrm{pH}$, and sampling soils. All agronomy-based technical skills that had advanced to the third round achieved final consensus. Table 3 illustrates identified agronomy-based technical skills and those achieving consensus in each round of the study. 
Table 4. Delphi Panel Results for Technology-based Technical Skills

\begin{tabular}{|c|c|c|}
\hline Round $1(n=16)$ & ound $2(n=16)$ & Round $3(n=16)$ \\
\hline Skill / Competency Identified & gly Agree/Agree $\%$ & Strongly Agree/Agree $\%$ \\
\hline Drafting and sending emails & 100 & 93.8 \\
\hline Using a laptop or desktop computer & 93.8 & 93.8 \\
\hline $\begin{array}{l}\text { Operating a mobile/smart phone (including } \\
\text { phone apps) }\end{array}$ & 93.8 & 87.5 \\
\hline Using Microsoft Excel & 87.5 & 87.5 \\
\hline Using Microsoft Word & 81.3 & 87.5 \\
\hline Using Microsoft PowerPoint & 68.8 & 87.5 \\
\hline Operating a tablet or iPad & 87.5 & 81.3 \\
\hline $\begin{array}{l}\text { Using Global Positioning Systems (GPS) } \\
\text { software/hardware) }\end{array}$ & 75.0 & 81.3 \\
\hline Using Google platforms (e.g. sheets) & 93.8 & 75.0 \\
\hline $\begin{array}{l}\text { Using autosteer technologies on farm } \\
\text { implements* }\end{array}$ & $62.5^{*}$ & - \\
\hline Using Variable Rate Technologies* & $62.5^{*}$ & - \\
\hline Using Geographic Information Systems (GIS) & $50.0^{*}$ & - \\
\hline Using Microsoft SharePoint* & $43.8^{*}$ & - \\
\hline Using aerial technology/drones & $37.5^{*}$ & - \\
\hline
\end{tabular}

Note. ${ }^{*}$ consensus not met

\section{Technology-based Technical Skills}

A total of nine technology-based technical skills achieved consensus. Most of the identified competencies were related to the use of computers, including drafting and sending emails, using a laptop or desktop computer, using a smart phone, and operating a tablet or iPad. Several competencies were related to specific programs such as Microsoft Excel, Microsoft Word, Microsoft PowerPoint, and related Google platforms. The use of Global Positioning Systems also achieved consensus; however, the use of Geographic Information Systems (GIS) and Variable Rate Technologies, identified in Round 1, failed to advance to the third round. Table 4 shows the identified technology-based, technical skills and those achieving consensus in each round of the study.

\section{Agriculture Mechanic/Operator-based Technical Skills}

Despite 12 agriculture mechanic/operator-based technical skills being identified in Round 1, only four advanced to the third round. Of the four that advanced, three achieved consensus at the conclusion of the Delphi. Two of the three dealt with safety: following safety practices around farm implements, and following safety practices during chemical applications. The third competency that reached consensus was the ability to drive a tractor. Competencies not achieving consensus but rated as agree or strongly agree by half or more of panel members included the ability to apply fertilizers and pesticides, and 
Table 5. Delphi Panel Results for Agriculture Mechanic/Operator-based Technical Skills

\begin{tabular}{|c|c|c|}
\hline Round $1(n=16)$ & Round $2(n=16)$ & Round $3(n=16)$ \\
\hline Skill / Competency Identified & Strongly Agree/Agree \% & Strongly Agree/Agree \% \\
\hline $\begin{array}{l}\text { Following safety practices around farm } \\
\text { implements }\end{array}$ & 87.5 & 100 \\
\hline $\begin{array}{l}\text { Following safety practices during chemical } \\
\text { applications }\end{array}$ & 87.5 & 100 \\
\hline Driving a tractor & 68.8 & 81.3 \\
\hline Inspecting farm implements* & 68.8 & $56.3^{*}$ \\
\hline Applicating fertilizers ${ }^{*}$ & $62.5^{*}$ & - \\
\hline Calibrating fertilizers and sprayers* & $62.5^{*}$ & - \\
\hline $\begin{array}{l}\text { Operating large equipment that requires a } \\
\text { CDL }^{*}\end{array}$ & $56.3^{*}$ & - \\
\hline Applicating pesticides* & $50.0^{*}$ & - \\
\hline Applying basic welding skills* & $50.0^{*}$ & - \\
\hline Repairing and maintaining small engines* & $43.8^{*}$ & - \\
\hline Operating a combine* & $37.5^{*}$ & - \\
\hline Applying basic carpentry* & $25.0^{*}$ & - \\
\hline
\end{tabular}

operating large equipment that requires a CDL. Table 5 illustrates the identified agriculture mechanic/operator-based technical skills and those achieving consensus in each round of the study.

\section{General Technical Skills}

Four general technical skills achieved consensus. Applying basic math skills was most agreed upon, followed by understanding of work benefits packages. Three-fourths of the panel agreed or strongly agreed that calculating liquid conversions and calculating percentages and fractions are desired competencies. Two competencies advanced to the third round of the study but did not achieve consensus: calculating chemical conversions and applying math skills without calculator assistance. Table 6 illustrates the identified general technical skills and those achieving consensus in each round of the study.

\section{Agribusiness-based Technical Skills}

Four agribusiness-based technical skills advanced from Round 2 to Round 3, and achieved consensus in the third round. Agribusiness-based technical skills achieving consensus included: accounting/bookkeeping; marketing agricultural services or products; implementing value-added products; and planning business operations. Table 7 
Table 6. Delphi Panel Results for General Technical Skills

\begin{tabular}{lcccc}
\hline Round 1 $(n=16)$ & Round $2(n=16)$ & & Round 3 $(n=16)$ \\
\cline { 1 - 1 } Skill / Competency Identified & Strongly Agree/Agree \% & & Strongly Agree/Agree \% \\
\hline Applying basic math skills & 100 & & 93.8 \\
Understanding of work benefits packages (e.g. & 68.8 & & 87.5 \\
retirement plans, health insurance) & & & \\
Calculating liquid conversions & 81.3 & & 75.0 \\
Calculating percentages and fractions & 81.3 & & 75.0 \\
Calculating chemical conversions & 68.8 & $62.5^{*}$ \\
Applying math skills without calculator & 68.8 & $56.3^{*}$ \\
assistance* & & \\
Understanding of animal husbandry* & $37.5^{*}$ & - \\
\hline
\end{tabular}

Note. ${ }^{*}$ consensus not met

Table 7. Delphi Panel Results for Agribusiness-based Technical Skills

\begin{tabular}{lccc}
\hline \multicolumn{1}{c}{ Round 1 $(n=16)$} & Round 2 $(n=16)$ & & Round 3 $(n=16)$ \\
\cline { 1 - 1 } Skill / Competency Identified & Strongly Agree/Agree $\%$ & Strongly Agree/Agree \% \\
\hline Accounting/bookkeeping & 87.5 & 75.0 \\
Marketing agricultural services or products & 81.3 & 75.0 \\
Implementing value-added products & 75.0 & 75.0 \\
Planning business operations & 68.8 & & 75.0 \\
Planning events & $31.3^{*}$ & & - \\
\hline
\end{tabular}

Note. ${ }^{*}$ consensus not met

shows the identified agribusiness-based technical skills and those achieving consensus in each round of the study.

\section{Discussion}

Nineteen panel members representing the breadth of agronomy-based agricultural industries within the college's district identified a total of 87 competencies important for community college agriculture program graduates when entering the local agricultural workforce. Of the 87 competencies identified by panel members, 58 reached consensus at the conclusion of the study and were categorized by emergent themes: soft skills (26), agronomy-based technical skills (12), technology-based technical skills (9), agriculture mechanics/operator-based technical skills (3), general technical skills (4), and agribusiness-based technical skills (4). The findings suggest that a combination of skilltypes are deemed important for entry-level agriculture positions.

Similar to prior research that analyzed agriculture industry's perceptions of competencies deemed essential in educational programs (Ramsey \& Edwards, 2011; 
Rinker et al., 2019; Sapp et al., 2019) and that are desired in the workplace (Easterly et al., 2017), findings indicated a strong employer demand for soft skills. A need for effective communication skills, including written and verbal communication, listening, and customer service were identified. Findings also support the need of a 21 st century agriculture workforce to be adept in problem solving and teamwork (National Research Council, 2009).

Results indicated that incumbent agriculture employees must be skilled in emerging agricultural technologies (Little, 2019; Parker et al., 2009). Nearly 90\% of panel members agreed that operating a smart phone, including phone apps, was an essential competency for entry-level employment. Employers also identified the need for employees to be able to operate a tablet or iPad and be proficient in Google Platforms (e.g., Sheets). Furthermore, over $80 \%$ of panel members agreed that using GPS software and hardware was an essential competency; however panel members failed to reach consensus on the ability to use other emerging technologies, such as Variable Rate Technologies, Geographic Information Systems, and drones.

Similar to Sapp et al. (2019), panel members in this study identified agronomyrelated competencies such as soil management, plant growth and nutrition, and pest control. The ability to follow safety practices around farm implements and during chemical applications was also deemed important. Lastly, applying math skills, including calculating liquid conversions and calculating percentages and fractions, reached consensus from the panel, also consistent with findings from Sapp et al. (2019). Interestingly, the need to apply math skills without calculator assistance did not reach consensus, perhaps exhibiting the changing role of technology assistance in the agricultural workplace.

As stated by Shinn et al. (2009) and Conner et al. (2013), a limitation to Delphi panels is that they are prone to not reach consensus on competencies too specific to a position. Panel members in this study were purposely selected to represent the breadth of agronomy-related industries within the college's district. Although it is believed the competencies reaching consensus adequately reflect desired skills among most employers in the district, some competencies not reaching consensus may be essential to some employers while deemed unessential to others. Competencies that were identified but that did not reach consensus, such as applying fertilizers and pesticides, can be analyzed on a case-by-case basis to inform program development. Contract training programs (Leigh, 2005; Spaulding \& Martin-Caughey, 2015) could be developed for desired competencies specific to medium and large enterprises within the district.

\section{Implications \& Recommendations}

The purpose of this study was to identify workplace competencies needed by community college agriculture program graduates within the college's district. Therefore, the results of this study are not intended to be generalizable to regions outside of the college's district. However, this research contributes a case study example of employer perceptions of the competencies needed by graduates of community college agriculture 
programs. This study can serve as a model for obtaining one important data set, among many, when conducting an employer needs assessment.

The results of this study can be used to inform agricultural education program development. Using the Understanding by Design framework (Wiggins \& McTighe, 2005), program development begins with the end in mind. The desired competencies identified by the agriculture employers in this study were specific to graduates of workready agriculture programs within the college's district. The identified competencies can be used to inform program and course learning outcomes of work-ready agriculture programs. This programmatic research follows the suggestions by Dougherty and Bakia (2000), who emphasized that regional economic development can be enhanced through industry-aligned, community college workforce education programs. Furthermore, this research adheres to the notion that community colleges can be leaders in workforce development when providing efficient educational experiences that are responsive to market demands (Levin et al., 2006).

Areas for future research are recommended. The research method used in this study was appropriate to statistically develop consensus from a group of subject matter experts. However, follow-up research that utilizes qualitative methods such as focus groups could provide additional details about desired employee competencies. Focus groups may be appropriate to identify existing employee skill gaps, desired organization of student internship opportunities, and perceptions of current strengths and weaknesses of existing work-ready programs. Similar research should be conducted in other community colleges districts both within and outside the Midwest. Comparison of such studies could yield insight if desired employee competencies are in fact unique to specific regions. Due to the changing nature of the agricultural industry (Little, 2019; National Research Council, 2009), it is also recommended that needs assessment research be a continuous effort. Program assessment and evaluation of postsecondary, prebaccalaureate agriculture programs will be a critical piece to improve workforce training in agriculture.

Community colleges will be essential in addressing the need for a qualified $21 \mathrm{st}$ century workforce in agriculture. The growing demand for middle-skilled jobs in the Midwest (NSC, 2017) requiring pre-baccalaureate education and training beyond high school is evident (Kansas Department of Agriculture, 2016). The technical skillset of the agricultural worker is also changing (Little, 2019; National Research Council, 2009). Work-ready agriculture programs forming strong alliance with the agriculture industry, and offering educational training that strengthens the human capital of regional agricultural industries, may be foundational to the livelihood of a new era in agriculture.

\section{References}

American Association of Community Colleges (2019). AACC fast facts 2019. https://www.aacc.nche.edu/research-trends/fast-facts/aacc-2019-fact-sheet/

Arteaga, C. (2018). The effect of human capital on earnings: Evidence from a reform at Columbia's top university. Journal of Public Economics, 157, 212-225. https://doi.org/10.1016/j.jpubeco.2017.10.007 
Journal of Research in Technical Careers

Athey, T. R., \& Orth, M. S. (1999). Emerging competency methods for the future. Human Resource Management, 38(3), 215-226. https://doi.org/10.1002/(SICI)1099050X(199923)38:3<215::AID-HRM4>3.0.CO;2-W

Beach, J. M. (2010). Gateway to opportunity?: A history of the community college in the United States. Stylus Publishing.

Becker, G. S. (1993). Human capital: A theoretical and empirical analysis, with special reference to education (3rd ed.). University of Chicago Press.

Carlisle, L., Montenegro de Wit, M., DeLonge, M. S., Calo, A., Getz, C., Ory, J., Munden-Dixon, K., Galt, R., Melone, B., Knox, R., Iles, A., \& Press, D. (2019). Securing the future of US agriculture: The case for investing in new entry sustainable farmers. Elementa Science of the Anthropocene, 7(1), 1-20. https://doi.org/10.1525/elementa.356

Carnevale, A. P., Smith, N., \& Strohl, J. (2013). Recovery: Job growth and education requirements through 2020. Georgetown University Public Policy Institute. https://cew.georgetown.edu/cew-reports/recovery-job-growth-and-educationrequirements-through-2020/

Cohen, A. M. (1998). The shaping of American higher education: Emergence and growth of the contemporary system. Jossey-Bass.

Cohen, A. M., \& Brawer, F. B. (1996). The American community college (3rd ed.). Jossey-Bass.

Conner, N. W., Roberts, T. G., \& Harder, A. (2013). Competencies and experiences needed by entry level international agricultural development practitioners. Journal of International Agricultural Extension Education, 20(1), 19-32. https://doi.org/10:5191/jiaee.2013.20102

Dalkey, N. C. (2002). Toward a theory of group estimation. In H. A. Linstone \& M. Turoff (Eds.), The Delphi method: Techniques and application (pp. 231-256). New Jersey Institute of Technology. https://web.njit.edu/ turoff/pubs/delphibook/delphibook.pdf

Diaz, J. M., Warner, L. A., \& Webb, S. T. (2018). Outcome framework for school garden program development and evaluation: A Delphi approach. Journal of Agricultural Education, 59(2), 143-165. https://doi.org/10.5032/jae.2018.02143

Dillman, D. A., Smyth, J. D., \& Christian, L. M. (2014). Internet, phone, mail, and mixed-mode surveys. The tailored design method. John Wiley \& Sons, Inc.

Dougherty, K. J. (1994). The contradictory college. State University of New York Press.

Dougherty, K. J., \& Bakia, M. F. (2000). Community colleges and contract training: Content, origins and impact. Teachers College Record, 102(1), 197-243. https://doi.org/10.1111/0161-4681.00052

Easterly, R. G., III, Warner, A. J., Myers, B. E., Lamm, A. J., \& Telg, R. W. (2017). Skills students need in the real world: Competencies desired by agricultural and natural resource industry leaders. Journal of Agricultural Education, 58(4), 225-239. https://doi.org/10.5032/jae.2017.04225

Edgar, L. D., Edgar, D. W., McGuire, A., Rutherford, T. A., Doerfert, D. L., \& Murphrey, T. P. (2012). Crises communication needs assessment: A Delphi study to enhance instruction for agricultural communicators and other stakeholders. NACTA Journal, 56(4), 52-62.

Erickson, B., Fausti, S., Clay, D., \& Clay, S. (2018). Knowledge, skills, and abilities in the precision agriculture workforce: An industry survey. Natural Sciences Education, 47, 111. https://doi.org/10.4195/nse2018.04.0010

Fletcher, J. A. (2017). Community college economic workforce development programs and financial insecurity. Community College Journal of Research and Practice, 42(5), 373 378. https://doi.org/10.1080/10668926.2017.1304295 
Geist, M. R. (2010). Using the Delphi method to engage stakeholders: A comparison of two studies. Evaluation and Program Planning, 33(2), 147-154. https://doi.org/10.1016/j.evalprogplan.2009.06.006

Grubb, W. N., \& Lazerson, M. (2004). The education gospel: The economic power of schooling. Harvard University Press.

Guo, W., Xiao, H., \& Yang, X. (2012). An empirical research on the correlation between human capital and career success of knowledge workers in enterprise. Physics Procedia, 25, 715-725. https://doi.org/10.1016/j.phpro.2012.03.148

Hampf, F., Wiederhold, S., \& Woessmann, L. (2017). Skills, earnings, and employment: Exploring causality in the estimation of returns to skills. Large-scale Assessments in Education, 5, 1-30. https://doi.org/10.1186/s40536-017-0045-7

Holzer, H. (2015). Higher education and workforce policy: Creating more skilled workers (and jobs for them to fill). The Brookings Institution. https://www.brookings.edu/research/higher-education-and-workforce-policy-creatingmore-skilled-workers-and-jobs-for-them-to-fill/

Jacobs, J., \& Dougherty, K. J. (2006). The uncertain future of the community college workforce development mission. In B. K. Townsend \& K. J. Dougherty (Eds.), New Directions for Community Colleges, 136, 53-62. https://doi.org/10.1002/cc.259

Jacobs, J., \& Worth, J. (2019). The evolving mission of workforce development in the community college (Working Paper No. 107). Community College Research Center. https://ccrc.tc.columbia.edu/media/k2/attachments/EvolvingMissionWorkforceDevelopm ent.pdf

Kansas Department of Agriculture (2016). Kansas agriculture workforce. https://agriculture.ks.gov/docs/default-source/default-document-library/workforcesurvey-results-fact-sheet.pdf?sfvrsn=1759b9c1_0

Kena, G., Musu-Gillette, L., Robinson, J, Wang, X., Rathbun, A., Zhang, J. Wilkinson-Flicker, S., Barmer, A., Velez, E. D. (2015). The condition of education 2015. National Center for Education Statistics. https://nces.ed.gov/pubs2015/2015144.pdfLangelett, G. (2002). Human capital: A summary of the 20th century research. Journal of Education Finance, 28(1), 1-23. https://www.jstor.org/stable/40704155

Leigh, D. E. (2005). Community college training and the workforce investment system. U.S. Department of Labor, Employment and Training Administration (Occasional Paper no. 15). https://wdr.doleta.gov/research/FullText_Documents/Community\%20College\%20Trainin g\%20and\%20the\%20Workforce\%20Investment\%20System\%20Report.pdf

Levin, J. S., Kater, S., \& Wagoner, R. L. (2006). Community college faculty: At work in the new economy. Palgrave Macmillan.

Little, A. (2019). The fate of food: What we'll eat in a bigger, hotter, smarter world. Penguin Random House.

Long, R. E., \& Morgan, A. C. (2010). The elements of two-year equine degree programs in the mid-western U.S.: A Delphi study. NACTA Journal, 54(2), 2-10. https://www.jstor.org/stable/nactajournal.54.2.2

Lukens, J. C. (2019). The future of higher education: How a students' decision to attend college is evolve [Honors thesis, DePauw University].https://scholarship.depauw.edu/studentresearch/113

Lundy, E. L., Andresen, C. E., Freeman, S. A., Loy, D. D., \& Gunn, P. J. (2017). Utilization of a modified Delphi method for needs assessment and curriculum revision of a senior-level 
beef systems management course. NACTA Journal, 61(3), 193-196.

https://www.nactateachers.org/attachments/article/2632/7\%20\%20Lundy.pdf

McClelland, D. (1973). Testing for competence rather than "intelligence". American

Psychologist, 28(1), 1-14. https://doi.org/10.1037/h0034092

McCracken, M., McIvor, R., Treacy, R., \& Wall, T. (2017). Human capital theory: Assessing the evidence for the value and importance of people to organizational success. CIPD

Technical Report. https://www.cipd.co.uk/Images/human-capital-theory-assessing-theevidence_tcm 18-22292.pdf

National Research Council. (2009). A new biology for the 21st century. National Academies Press.

National Skills Coalition. (2017). Illinois'forgotten middle. https://m.nationalskillscoalition.org/resources/publications/2017-middle-skills-factsheets/file/Illinois-MiddleSkills.pdf

Organisation for Economic Cooperation and Development (2015). Entrepreneurship at a glance 2015. https://www.oecd-ilibrary.org/industry-and-services/entrepreneurship-at-a-glance2015_entrepreneur_aag-2015-en

Parker, R., Brase, T., Dewsnup, M., Anderson, M., Collins, A., Klopp, D., Johnson, B., \& Feldmann, H. (2009). Changing agricultural education to meet needs of emerging careers. Community College Journal of Research and Practice, 33(11), 977-979. https://doi.org/10.1080/10668920903153477

Peregrin, T. (2014). Competency-based hiring: The key to recruiting and retaining successful employees. Journal of the Academy of Nutrition and Dietetics, 114(9), 1330-1331. https://doi.org/10.1016/j.jand.2014.07.016

Ramsey, J. W., \& Edwards, C. E. (2011). Entry-level technical skills that agricultural industry experts expected students to learn through their supervised agricultural experiences: A modified Delphi study. Journal of Agricultural Education, 52(2), 82-94. https://doi.org/10.5032/jae.2011.02082

Rinker, S. P., Hainline, M. S., \& Smalley, S. W. (2019, May). Identifying the professional and technical skills agricultural industry employers expect agricultural graduates to possess. [Paper presentation]. American Association for Agricultural Education National Conference, Des Moines, IA, United States.

Sapp, S., Thoron, A. C., \& Rubenstein, E. D. (2019). Knowledge, skills, and competencies needed by students with training in agricultural and environmental practices as perceived by local leaders: A Delphi study. Journal of Southern Agricultural Education Research, 69(1), 65-83. http://www.jsaer.org/pdf/Volume\%2069\%20publish.pdf

Scheer, S. D., Cochran, G. R., Harder, A., \& Place, N. T. (2011). Competency modeling in extension education: Integrating an academic extension education model with an extension human resource management model. Journal of Agricultural Education, 52(3), 64-74. https://files.eric.ed.gov/fulltext/EJ956089.pdf

Shinn, G. C., Wingenbach, G. J., Briers, G. E., Lindner, J. R., \& Baker, M. (2009). Forecasting doctoral-level content in international agricultural and extension education-2010: Viewpoint of fifteen engaged international scholars. Journal of International Agricultural and Extension Education, 16(1), 57-71. https://doi.org/10.5191/jiaee.2009.16105

Soliz, A. (2016). Preparing America's labor force: Workforce development programs in public colleges. The Brookings Institution. https://www.brookings.edu/research/preparingamericas-labor-force-workforce-development-programs-in-public-community-colleges/

Spaulding, S. \& Martin-Caughey, A. (2015). The goals and dimension of employer engagement in workforce development programs. The Urban Institute. 
https://www.urban.org/sites/default/files/publication/76286/2000552-the-goals-anddimensions-of-employer-engagement-in-workforce-development-programs_1.pdf

Stewart, J. (2001). Is the Delphi technique a qualitative method? Medical Education, 35(10), 922923. https://doi.org/10.1111/j.1365-2923.2001.01045.x

Torpey, E. (2018). Employment outlook for occupations requiring an associate's degree, certificate, or some college. United States Bureau of Labor Statistics. https://www.bls.gov/careeroutlook/2018/article/postsecondary-outlook.htm

United States Department of Labor (n.d.). Trade adjustment assistance community college career training. Employment and Training Administration. https://www.dol.gov/agencies/eta/tradeact/community-colleges

United States Department of Labor (2018). TAACCCT program fact sheet. Employment and Training Administration. https://www.dol.gov/sites/dolgov/files/ETA/TAACCCT/pdfs/TAACCCT-Fact-SheetProgram-Information.pdf

Warner, L. A. (2014). Using the Delphi technique to achieve consensus: A tool for guiding Extension program. University of Florida IFAS EDIS, Florida Cooperative Extension Service Electronic Data Information Source, Publication AEC521. https://edis.ifas.ufl.edu/wc183

Wiggins, G. P., \& McTighe, J. (2005). Understanding by Design. Association for Supervision and Curriculum Development.

Whittaker, J. G., \& Williams, G. (2016). Skills gap - A strategy for increasing knowledge worker supply and demand. Journal of Business, 1(4), 13-24. http://doi.org/10.18533/job.v1i4.42 